\title{
Impact of Climate, Climate Change and Modern Technology on Wheat Production in Nepal: A Case Study at Bhairahawa
}

\author{
Janak Lal Nayava ${ }^{1}$, Rabi Singh ${ }^{2}$, Madan Raj Bhatta ${ }^{3}$ \\ ${ }^{1}$ Freelancer Consultant in Agro-meteorology \\ Email:drjanaklal@yahooo.com \\ ${ }^{3}$ National Wheat Research Project, Bhairahawa
}

\begin{abstract}
The relation between climate and wheat production in Nepal was studied for the period 1970/71-2007/08. Due to the topographical differences within short north-south span of the country, Nepal has wide variety of climatic condition. About 70 to $90 \%$ of the rainfall occurs during the summer monsoon months (June to September) in Nepal and the rest of the months are almost dry. Wheat is cultivated during the dry winter period and therefore, the supplementary irrigation plays a vital role in its cultivation. Varieties of wheat have been developed to suit the local climatic conditions. Due to the availability of improved seeds, modern cultivation practice and a supplementary irrigation; the wheat cultivation has increased substantially throughout Nepal. The national area and production of wheat has remarkably increased from 228,000 ha to 706,481 ha and $193360 \mathrm{mt}$ to 1,572,065 mt during 1970/71 to 2007/2008 respectively. Future planning to increase the wheat production in Nepal should give due consideration to the effect of global warming also. The present rate of annual increase of temperature was $0.06^{\circ} \mathrm{C}$ in Nepal. Trends of temperature rise were not uniform in Nepal. An increase of annual temperature at Bhairahawa during $1970-2008$ was only $0.018^{\circ} \mathrm{C}$. However, the wheat growing seasons at Bhairahawa, the trend of annual maximum temperature during November to April was $-0.0068^{\circ} \mathrm{C}$ during the study period. Though modern facilities such as irrigation, improved seeds and fertilizers are available to some extent, weather and climate still plays an important role in the increase of area and production of wheat in Nepal
\end{abstract}

Key words: climate change, plain low land (phant), global warming, trend

\section{INTRODUCTION}

For any crop grown in an area, it is better to have description of physiographic, types of soils and their field capacity and climates of the area. Due to the topographical differences at the shortest distance almost all types of climates prevail in Nepal. In Nepal wheat is grown in the temperate climate and subtropics. Wheat is the third largest cereal crop in Nepal. Now the country produces 1.57 million $\mathrm{mt}$ and exports wheat to the other countries.
It is desirable that the minimum and maximum temperature during the wheat growing period should be $3^{\circ} \mathrm{C}$ to $32^{\circ} \mathrm{C}$ respectively and the mean daily temperature for optimum growth is between $20^{\circ} \mathrm{C}$ and $25^{\circ} \mathrm{C}$ (Briggle, 1980). Knowledge of genetic characteristics and particularly growth and development pattern of wheat varieties is essential for meeting the combination of various climatic requirements for growth development and yield formation. It is known that the upper limit of crop production is set by the climatic condition specially 
temperature regimes and the genetic potential of the variety grown. The extent to which this limit can be reached will always depend on how finely the engineering aspects of water supply are in tune with the biological needs for water in crop production (FAO, 1979). For higher yields, water requirements are 350-500 mm depending on climate and length of growing period in Nepal. There should be adequate water during the establishment period. Water deficit during the filling period results in reduced grain weight. However, during the ripening and drying-off period, rainfall or irrigation have negative impact on the yield. The area under wheat cultivation in different regions of Nepal is shown in Figure 1. For administrative purposes, the country is divided into five Regions. Each Region has Tarai, Hills and Mountain.

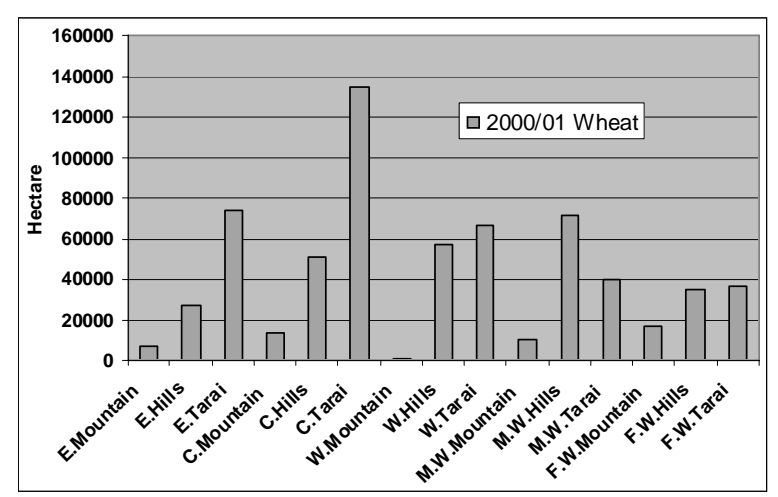

Figure 1: Wheat cultivation in the different regions in Nepal

\section{DATA}

This study has used thirty eight years (1970/71 2007/08) of crop data in Nepal. Weather data were made available by the Department of Hydrology and Meteorology (DHM). Source of the wheat data is the then Department of Food and Agricultural Marketing Services (DFAMS), National Planning Commission (NPC), Central Bureau of Statistics (CBS) and Ministry of Agriculture and Cooperatives (MoAC).

Taking into consideration the winter rainfall and the growing season of wheat, this study attempts to cover whole of Nepal and three ecological belts and a case study at one National Wheat Research Centre at Bhairahawa in Tarai, where the irrigation facilities are available.

\section{ANALYSIS}

\subsection{NATIONAL LEVEL}

While observing the wheat yield and their production in Nepal during 1970/71 to 2007/08, the area was about 228,400(Two hundred twenty eight thousands and four hundred) hectare during 1970/ 71 and in 2007/08, the area has increased to 706,481 (seven hundred and six thousand four hundred eighty one) hectare. There is clear indication that the area under wheat cultivation has increased more than three folds in 2007/2008 during the study period. The wheat production was 193,360 (one hundred ninety three thousand and three hundred sixty) mt in 1970/71 and now the production is 1,572,065 (on average 1.57 million) $\mathrm{mt}$ in 2007/08. The wheat production during the study period of 1970/71-2007/08 has increased more than eight fold. The wheat production during 2008/2009 will be much lower in Nepal compared to the previous year due to the long period of dry spell and warm period during this wheat season. Especially, wheat depended on rainfall would be badly affected in Hills and Mountain in Nepal.

Nepal Agriculture Research Council (NARC, 1997) mentioned that performance in wheat production in Nepal has increased remarkably due to wide spread cultivation of high yielding varieties since 1972. Although attempts on variety development were initiated since late fifties, the systematic breeding works began only after the establishment of National Wheat Development Program in 1972. In fact Department of Agriculture had launched a "Grow More Wheat Campaign" in 1965/66 with the introduction of Mexican wheat varieties introduced via India. The new varieties of seed were launched since then and now occupy $96 \%$ in 2006/2007(MOAC, 2006). There are 
altogether 30 varieties developed for different environment in Nepal (NARC, 2007). The national wheat area and production from 1970/71 to 2007/ 08 are shown in Figure 2. Initially during the first decade, the yield was almost constant and in the later part the yield increased to more than $2 \mathrm{mt}$ per hectare as shown in Figure 2. This is clearly due to improved modern technology and adoption of high yielding varieties as well as supplementary irrigation.

The Department of Irrigation has claimed that more than one million hectares was irrigated in Nepal during 2007/08 (MOAC, 2008). Traditionally there are a hundreds of small temporary water channels managed by local farmers since long before. It is estimated that as of 2002 government agencies and farmers have developed irrigation infrastructure covering about 1,121,441 ha. Of this farmer managed (but intervened by Department of Irrigation) system cover about 59\%, farmer managed system(not yet intervened) cover $27 \%$ and the rest $14 \%$ area is irrigated by those farmer managed irrigation systems supported by $\mathrm{ADB} / \mathrm{N}$ (Sharma, 2004).

Recently available data reveals that net command area of government assisted farmer managed systems is 334,237 ha and area of farmer developed and farmer managed systems is 276,219 ha. Furthermore, area under ground water projects (most of them managed by farmers) is reported to be 230,275 ha. Area irrigated by Agency Managed Irrigation Systems (AMIS) is 280,710 ha (DOI, 2004). It will be interesting to find out that how much different irrigation systems had all year round facilities and how much irrigated systems had a capacity of serving irrigation in winter time.

There was the Special Program on Food Production in support of Food Security In Nepal (SPIN) implemented by the Department of Agriculture and Department of Irrigation and FAO in several irrigation systems of two hills (Syangja and Ilam) and two Tarai (Nawalparasi and Jhapa) districts during 1995 to 1998 . The study showed that the wheat crop yield showed an increase of $110 \%$ over the base yield with the introduction of improved package of technology (Sharma K.R. 1998).

By the end of this century, the average increase of temperature would be between $1.5^{\circ} \mathrm{C}$ to $4.5^{\circ} \mathrm{C}$ in the world (IPCC, 2007). It is interesting to know that the annual warming in the Himalayan region between 1967 and 1994 was $0.06^{\circ} \mathrm{C}$. Trends of temperature rise were not uniform in Nepal, but the Himalayan region seemed to have much more increase of temperature than the lower elevation (Shrestha et al. 1999). Retreat of glaciers and forming the new lakes are a fresh example of global warming in Nepal. Bursting the glacial lake means flooding followed by the disaster on that area. This is a really hot topic and understanding the holistic system of Himalayan water and their future role of water supplies for agriculture and hydro power and so and so forth. There seemed to be no fixed pattern of annual rainfall in Nepal except slightly decreasing trend in the Far Western Nepal and the intensity of rainfall appeared to increase (Nayava, 2004). The inter-annual variation of monsoon rainfall and their impact in rice yield and production are very interesting and the lessons can be learnt from those studies (Nayava, 2008).

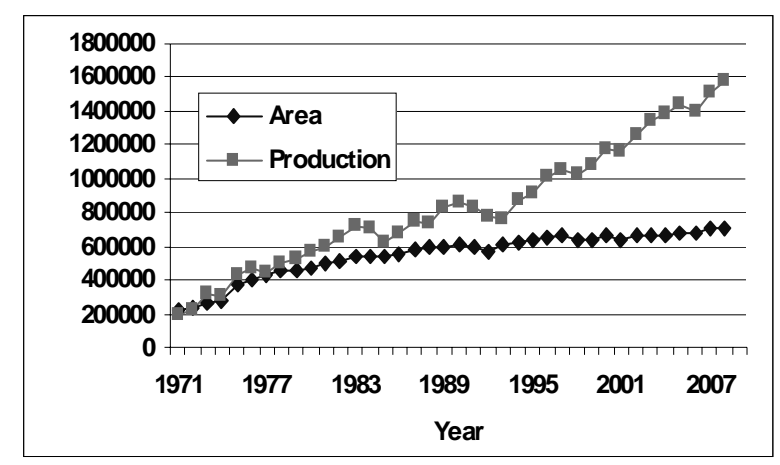

Figure 2: The National wheat area and production

\subsection{ECOLOGICAL BELTS}

The wheat area and production in three ecological belts are as follows: 


\section{MOUNTAIN}

In course of studying wheat cultivation in three ecological belts, the Mountain region showed that the increase of area has almost doubled and the yield increased to the little above 50\% during the last 38 years. The gap of the area and production showed a change after 1995 in the Mountain (Figure 3). This can be attributed to the improvement of technology of wheat farming. The production of wheat in the Mountain region increased from 28,900 $\mathrm{mt}$ to $83,739 \mathrm{mt}$ during the last 38 years from 1970 / 71 to 2007/08. During the wheat growing season (November to May) in the Mountain region, the rainfall is about 150 to $250 \mathrm{~mm}$, but the nature of rainfall was very erratic. The average annual temperature during the growing season in Mountain was $6^{\circ} \mathrm{C}$ to $18^{\circ} \mathrm{C}$. The annual temperature trend in the Mountain region at selected place in Jumla, $2300 \mathrm{~m}$ was observed only $0.035^{\circ} \mathrm{C}$ during the 1977 2008. In fact Mountain region as defined include only $7.6 \%$ of the total wheat area and contributes $5.3 \%$ of the total wheat production in the country.

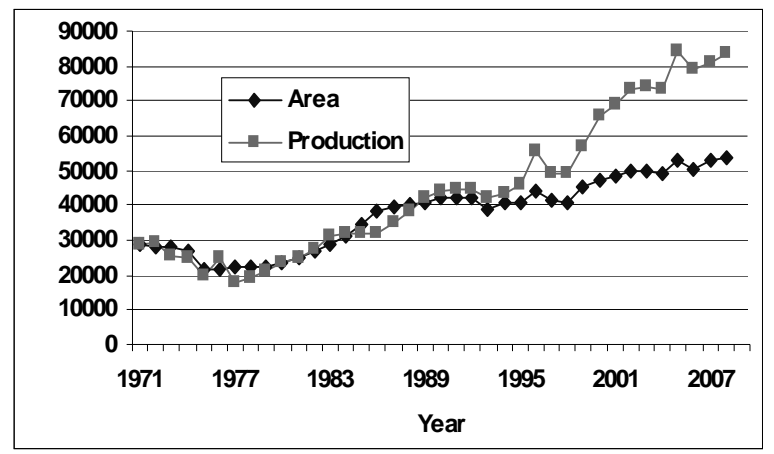

Figure 3: The wheat area and production in Mountain

\section{HILLS}

During the wheat growing season (November/ December to April/May) in the Hills Region, the rainfall is about 100 to $200 \mathrm{~mm}$ with higher distributions in the Western Hills than the Eastern Hills. Therefore, the cultivation of wheat area is more in the Western Hills than the Eastern Hills as shown in Figure 2. Mean annual temperature during the growing period in the Hills ranged from $9^{\circ} \mathrm{C}$ to $24^{\circ} \mathrm{C}$. The annual temperature trend in the Hills Region at selected places in Surkhet was observed only $0.028^{\circ} \mathrm{C}$ during the $1977-2008$. The Hills region showed nearly three fold increase of area and the yield showed $100 \%$ increase during the same period from 1970/71 to 2007/08. The gap of the area and production showed a change after 1988 in the Hills (Figure 4). The production of wheat in the Hills region increased from 82,800 $\mathrm{mt}$ to 447,791 mt during the study period. In fact Hills region as defined include only $34.57 \%$ of the total wheat area and contributes $28.5 \%$ of the total wheat production in the country.

In the mid Hills, there is significant area under wheat that is very similar to Tarai in terms of varieties grown. For example in Tarai, Tars and many river basin areas of mid Hills, Tarai varieties are grown. If one sees wheat in the mid and Far-Westen Hill districts, all good production comes from river basins and plain areas in the foot hills (it is called Phant such as Dipayal phant, Sakayal phant, Bandungrasain phant etc. in Doti, Dadeldhura districts). In general there are $57.8 \%$ the area of wheat which lies in the Tarai and similar environment contributes about $66.2 \%$ of the country's total wheat production. Rest goes to Hills and Mountain.

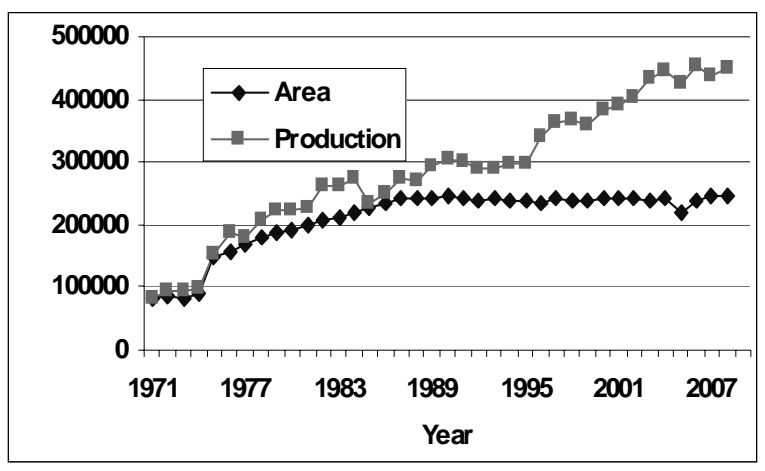

Figure 4: The wheat area and production in Hills 


\section{TARAI}

The wheat is grown during winter (November/ December to March/April) in Tarai. During this period about 2 to 5 percent (less than $100 \mathrm{~mm}$, more precisely $30-90 \mathrm{~mm}$ ) of seasonal rainfall occur in the Tarai. These winter rains are very irregular and erratic in nature. In Nepal, 70 to $90 \%$ of rainfall occurs in the summer monsoon and the rest of the months are almost dry. Distribution of winter rainfall is more in the Western Tarai than in the Eastern Tarai. The winter rain caused by westerly disturbances originates from the Mediterranean Sea. Annual mean temperature during the growing period of wheat in Tarai is $15^{\circ} \mathrm{C}$ to $30^{\circ} \mathrm{C}$. The annual temperature trend in the Tarai Region at the selected place in Bhairahawa was observed only $0.005^{\circ} \mathrm{C}$ during the $1977-2008$. In fact Tarai region as defined include $57.82 \%$ of the total wheat area and contributes $66.2 \%$ of the total wheat production in the country.

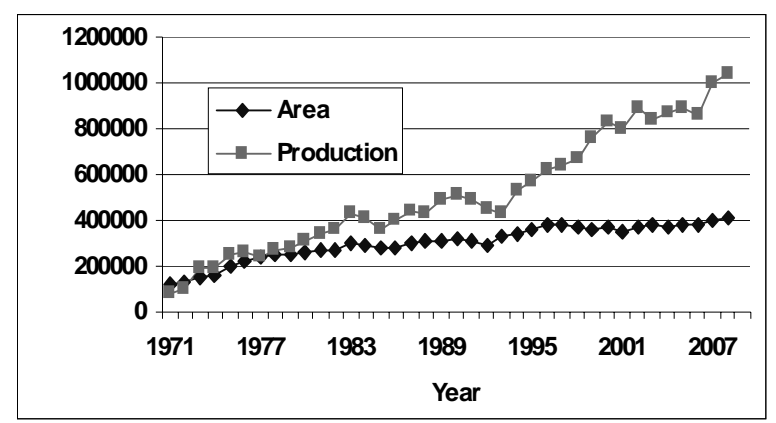

Figure 5: The wheat area and production in Tarai

During the last 38 years period from 1970/71 to 2007/08 (Figure 5), the production of wheat in the Tarai region increased from 81,600 mt to 1,040,535 $\mathrm{mt}$. It is interesting to note that the wheat yield in Tarai was initially lower. After the introduction of high yield varieties and irrigation facilities, the yield increased more than those of the Hills and Mountain. In Tarai alone area under wheat increased by $350 \%$ and its yield increased three fold. The harvesting of wheat is about a week earlier in Western Tarai than in the Eastern Tarai due to the temperature differences.
In terms of development of wheat at three different ecological belts, the productivity is measured by yield and therefore the yield at three ecological belts are presented in Figure 6, which shows that the yield is much higher in Tarai than in the Hills and the Mountain region. In cereal production, the progress in wheat has had remarkable achievement in Nepal. Especially wheat in Tarai had very much improved due to partial irrigation and use of high yielding varieties. Due to recent global warming, Tarai may be badly affected. The above discussions were the general studies of climate and wheat in three distinct Regions of Nepal. But one has to go very much detailed study at a place for the impact of climate constraints and their change and therefore Bhairahawa has been considered for a meso-scale study to find the relationship between climate and wheat.

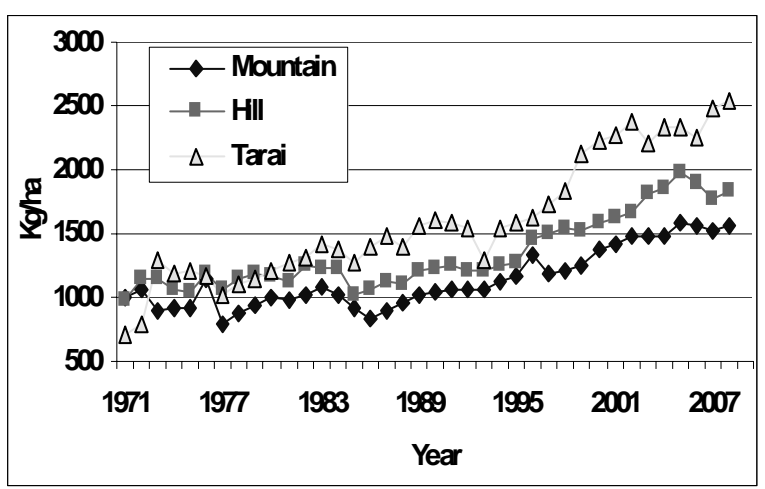

Figure 6: The wheat yield at three ecological belts

\section{A CASE STUDY: NATIONAL WHEAT REASEARCH CENTRE, BHAIRHAWA IN TARAI}

The simplified mathematical model known as growth indices developed by Fitzpatrick and Nix (1970) was calibrated in the Nepalese environment by Nayava(1981) and is presented with data from the Wheat Research Centre, Bhairahawa, a district in Western Nepal (Figure 7a and Figure 7b). Bhairahawa is a low land in plain area and dominantly prevails with alluvial clay soil. 


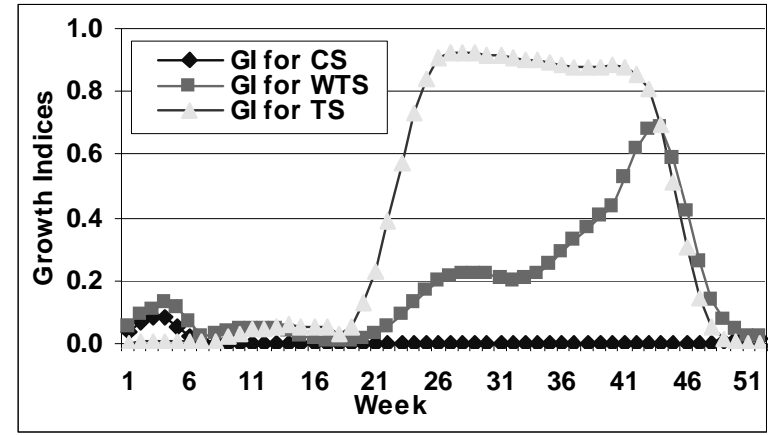

Figure 7a: Growth Indices at Bhairahawa, $109 \mathrm{~m}$ at rain-fed conditions

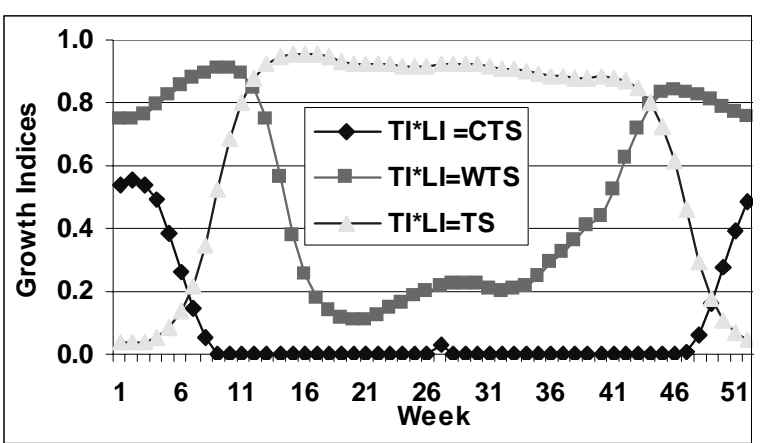

Figure 7b: Growth Indices at Bhairahawa, $109 \mathrm{~m}$ at Irrigated conditions

The growth Indices (G.I.) considers light (LI), thermal (TI) and moisture regimes (MI) into a linear function with a scale ranging from zero to unity. In this analysis, growth indices (G.I.) has been defined as most favorable G.I. (higher than 0.8), fairly favorable G.I. (0.4 to 0.8) and least favorable G.I. (less than 0.4) are defined. The most favorable is the optimum climatic potential for cultivation where all environmental indices such as light, thermal and moisture have almost non-limiting condition for growth, such as growth index higher than 0.8 . The Figure $7 \mathrm{a}$ indicate that only one tropical species (TS) can be grown under optimum condition during the week 25 to 43 (June 18 - 24 to October 23 29) as rain-fed condition in summer season. Figure $7 \mathrm{~b}$ show that the three crops (two tropical species during the week 11 to 44 (March 12 - 18 to October 30 - November 5) and one warm temperate species (WTS) as wheat during the week 44 to 12 (November 30 - December 5 to March 19 - 25) can be easily managed with proper irrigation facilities. Cold temperate species (CTS) can not be grown in rain-fed as well as irrigated condition.

Thus, only one crop as tropical species can be cultivated in the rain-fed condition for optimum yield during the summer monsoon as shown in Figure 7a. The second and third crop can be managed only by irrigation application as described earlier and is shown in Figure 7b. However, wheat sowing in Tarai can be delayed up to the second week of December without significant reduction in yield. Wheat seeds sown beyond these dates resulted yield reduction of 30 to $50 \mathrm{~kg} / \mathrm{day} / \mathrm{ha}$ (NARC, 1997). When weather and climate relate with agriculture, one has to study the diurnal variation as well as short term climate data such as weekly and ten days mean with reference to daily data are needed to see the relation between climatic parameters with crop cycle. As a matter of fact, the energy and moisture balance are very necessary for crop under study.

The Figures $7 \mathrm{a}$ and $7 \mathrm{~b}$ reveal that without the supplementary irrigation, the present yield and production in wheat yield is not possible in Nepal especially in the Tarai region. Whatever one grows, whether under rain-fed or irrigated conditions, one should be aware of weather and climatic conditions to have expected production. Without efficient use of water, our target production may never be achieved. It is high time to document the use of irrigation facilities in Nepal in detail, so that one should know how much water has been really used and what strategy has to be considered in future.

It is very interesting to note that the wheat yield in Tarai, Hills and Mountain justify the crop weather model patterns as described earlier. According to crop weather model, the Tarai is most favorable, the Hills and Mountain are only favorable. The results were tallied by yield pattern in different ecological belt as discussed earlier. 
The crop data are available only in district wise and the Bhairahawa belongs to the Rupandehi district. The development of wheat started from Bhairahawa Agricultural farm in Rupandehi district during the early 1970's. Initially the area of wheat as well as yield in Rupandehi district was very low as shown in Figures $8 \& 9$ and only later the development of wheat took place as already described.

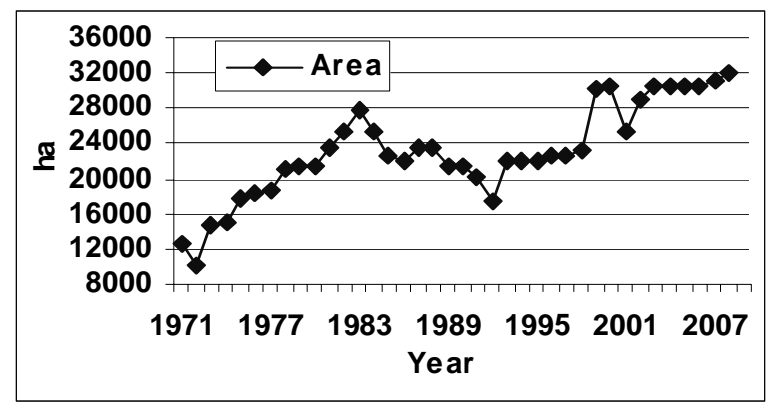

Figure 8: Wheat area in Rupandehi

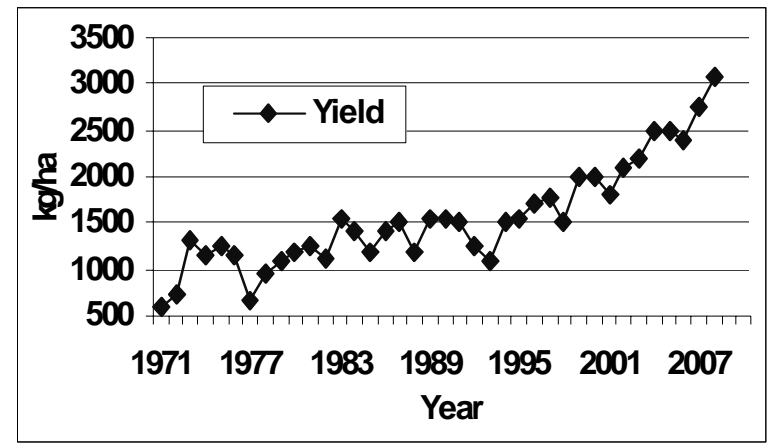

Figure 9: Wheat yield at Rupandehi

In that present scenarios of climate change, detailed study of crop and climate relation during the particular cropping period are required, whether that period has any changes from normal pattern or possible departure which may affect the crop in stand.

During the wheat growing season in November/ December to March, the normal rainfall during 1970/71-2006/07, the rainfall was $88.6 \mathrm{~mm}$ and the number of rainy days was 7 days. Below normal or less than $87 \mathrm{~mm}$ of rainfall was experienced in 26 years out of 37 years. Only 7 years showed more than $100 \mathrm{~mm}$ of rainfall. During those 37 years, 7 years had less than $25.0 \mathrm{~mm}$ of rainfall. Though such a poor rainfall and a few rainy days, the cultivation of wheat area has been increasing as shown in Figure 8 and at the same time the yield per hectare has also been increasing as shown in Figure 9. It is purely due to the development and uses of high yielding varieties as well as availability and uses of irrigation facilities.

It has been mentioned that depending upon the availability of water, irrigation in wheat crop is recommended at the crown root initiation stage (2530 days after showing), at the heading stage and at the grain filling stage (NARC, 1997).In general, it seems that the increase of land area and yield were both due to irrigation facilities. Otherwise, it was not possible to get higher yield without irrigation. A supplementary irrigation by ground water project in Bhairahawa is worth mentioning. On the contrary, the relationship between rainfall and wheat yield is very complex due to non availability of data on irrigation applications. It is certain that rainfall distribution in February and March had a very good impact on yield. There seemed that the most of the up and down cultivation of wheat area was a result of October rainfall and it helped as residual moisture during planting time. In addition to supplementary water, the improved varieties of seeds may have had a role for higher yield in Bhairahawa. From 1998, the wheat yield increased from 1800 to above $2500 \mathrm{~kg} /$ hectare. The use of HYV seeds can increase yield by 15 to $25 \%$ (Cox, 2000). This jump in wheat yield is partly due to application of increased fertilizer inputs over time too. The causes of recent increment of yield are attributed to the uses of high yielding seeds which have been confirmed by personal discussion with the concerned authorities, however the concerned authorities should take seriously this matter in future estimation.

The production of wheat in Rupandehi district was shown in Figure 10. It is very unfortunate that when and how much water had been added by the irrigation was not available. This is a matter of 
study required in future. The production of wheat in Rupandehi district was shown in Figure 10.

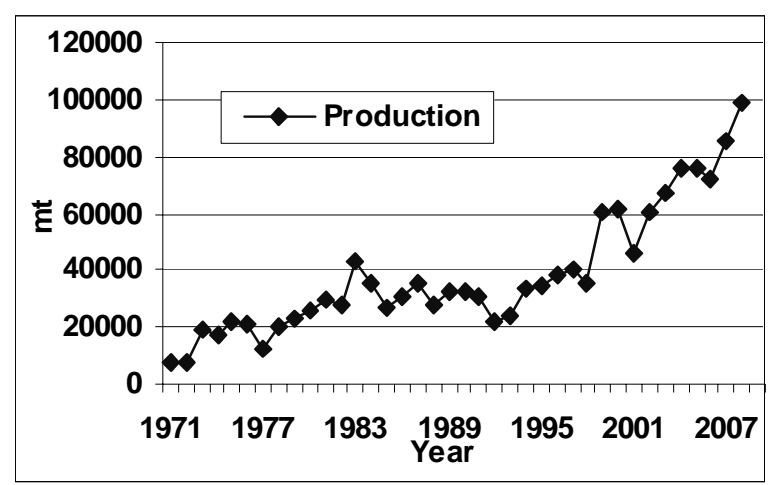

Figure 10: Production of wheat in Rupandehi district

\section{CLIMATE CHANGE AND THEIR EFFECTS ON WHEAT}

In the present scenarios of climate change, the overall impact of agriculture has to be explored and this is very enormous task and very complex, but the country should immediately start planning and take action, before it is too late. The maximum and minimum temperature trend during the wheat growing season from November to April was also analyzed as shown in Figures 11-12. The maximum temperature showed negative trends which was $0.0068^{\circ} \mathrm{C} /$ year during $1970-2008$ at Bhairahawa as shown in Figure 11. On the contrary, the minimum temperature showed increase in $0.030^{\circ} \mathrm{C}$ at the same period as shown in Figure 12. However, the mean annual temperature during November to April showed $0.012^{\circ} \mathrm{C}$ during 1970 to 2008 as shown in Figure 13. It showed that the increase of temperature seemed more in the recent decade than the former decade. Due to frequent cold waves in the Tarai as mentioned before, the temperatures were dropped considerably during winter months. Cold waves had occurred during late December and January and these have not much affected, but for wheat yield and production are concerned, temperature regimes from November to whole of March are very important especially for the Tarai region where as in the Hills, yield is more affected by drought rather than temperature regimes.

Journal of Hydrology and Meteorology, Vol. 6, No. 1

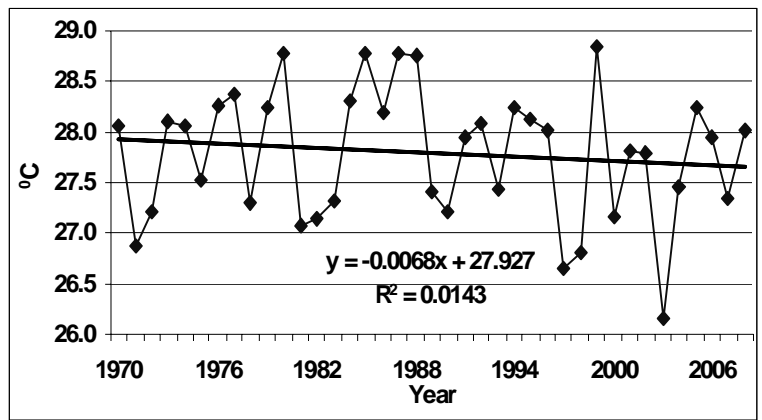

Figure 11: Trend of maximum temperature during (November - April)

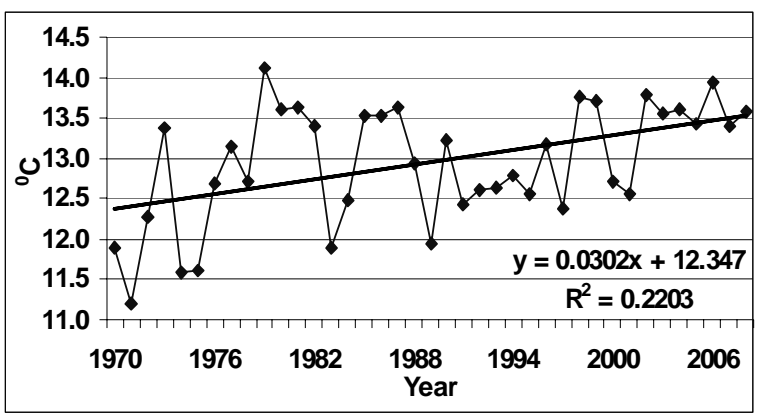

Figure 12: Trend of minimum temperature during (November - April)

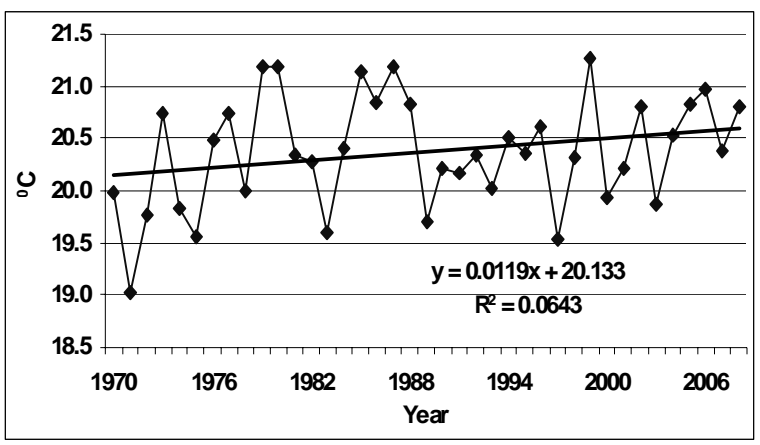

Figure 13: Trend of mean temperature during (November-April)

It is interesting to note that after peak area of wheat achievement in 1983, the decrease of wheat cultivation was noted up to 1998 and latter the area of wheat has been increasing trend as shown in figure 8 . Another puzzling factor, the yield showed sharp up and down in different years. While looking at the upward trend of yield in Figure 9, the sharp decreased of yield during 1976/77, 1981/82, 1984/ 
85, 1987/88, 1991/92, 1992/93, 1997/98, 2000/01 and 2005/06 are note worthy to discuss and find out the causes. It is known that the temperature is a limiting factor for any plant growth. The temperature regimes during post anthesis are very critical. The minimum temperature during February and March in Bhairahawa was very critical and it affected the yield. The weekly minimum and maximum temperature in Bhairahawa Agricultural Farm during February and March in 2000 to 2007 was observed. During 2006, no rainfall was observed during winter months and the increased in minimum temperature was noted and that affected wheat yield. Thus up to $60 \%$ variations of productivity of wheat depended on weather fluctuation. This is a matter for study in future at different temperature regimes in Nepal and extensive field works are necessary to collect the information on fertilizer application, irrigation, time of weeding and their cultural practices.

The mean temperature during November to March at Bhairahawa since 1971-2007 was observed to be between $15.1^{\circ} \mathrm{C}$ to $22.7^{\circ} \mathrm{C}$. During the occurrence of cold waves in 1982/83, 1992/93, $1997 / 98,1998 / 1999$, the mean temperature in January was observed to be $13.8^{\circ} \mathrm{C}, 13.7^{\circ} \mathrm{C}, 13.7^{\circ} \mathrm{C}$ and $14.5^{\circ} \mathrm{C}$ respectively. The drop of maximum temperature as much as $10^{\circ} \mathrm{C}$ was noted during the cold waves, it seemed that those cold waves occurred mostly during the vegetative period of wheat and therefore that cold wave did not affect much in the wheat performance significantly. But those cold waves had much affected in the vegetables.

Recently the effect of climate change to agriculture in Nepal was also studied by different researchers. The latest report shows that there is positive role in percentage change in wheat yield in all the agroecological zones. With doubling of carbon dioxide, wheat production is likely to increase with adoption of more heat tolerant varieties (Sharma, 2007). The study of present variation of climatic parameters such as rainfall and temperature in the crop yield should be regularly studied and discussed. The diurnal variation as well as short term temperature such as weekly and ten days mean with reference to daily temperature are needed to see the relation between climatic parameters with crop cycle. Recently the trend of minimum temperature was observed to have increased during February and March in 2006 and the rainfall was nil during November to February, 2006. This resulted poor wheat yield in Bhairahawa. Similar study should attempt in different places of Nepal to verify those cases. Unless the full investigations of crop under study, the adaptation and mitigation would be premature to be prescribed.

\section{MARKETING / VALUE CHAIN APPROACH IN WHEAT CROP}

Agriculture sector provides livelihood for more than 80 percent of population and accounts for about 36 percent of the Gross Domestic Product. Among various crops and commodities, contribution from the cereals is significant. After rice and maize, wheat is the third largest and important cereal crop which contributes about 20 percent of the total cereal production in the country. Besides developing and or capitalizing on research, technology, extension/training, farm roads, round the year irrigation system, credit services, market oriented agri-business approaches to each and every crop/ commodity is a must in order to secure competitive edge for Nepal. It is more important under the regional and other world trade regimes particularly governed by the World trade Organization (W.T.O).

Nepal needs to take comparative advantage of its ecological sites/belts to make its produce competitive. One significant aspect which Nepal should consider is to see how the India's agricultural/ economic policy is framed particularly when viewed in terms of porous open border between these two countries. It is generally observed that the prices of India's agricultural produces are low due to relatively higher agricultural subsidies. India provides both for activities associated with inputs and outputs. Also review of agricultural policy in the SAARC region necessary in order to make 
Nepalese produce competitive in these countries as well. Overseas markets for niche products such as tea, coffee, honey, cardamom are also important where access to these products so far has been due to their organic nature more by default. This however, needs improvement supported by research, supervision and creating international standard laboratory facilities in the country.

Wheat crop is relatively new in Nepal. It basically envelops cultivation of the exotic high yielding varieties. Both area and production under the crop are increasing over the years. Its production has been more than quadrupled from 223 thousand $\mathrm{mt}$ in 1972 to the present year's production level. And similarly the area has increased to a considerable extent. Wheat tremendously helped in increasing the food supply level vis -a vis the food security of the country. In addition to that, wheat flour export to Tibet and Bangladesh has remained significant. However, there is a need to focus on the areas. Such a variety selection to match the industrial (processing) demand and secondly the production concentration or the production area zoning, thirdly meeting the consumer demand and fourthly meeting the export demand. For this, production and productivity level efficient networking of valuechain stakeholders, sound marketing and or agribusiness approach has to be raised and developed as well as enhanced together with enterprise friendly related rules and regulations in order that wheat crop remains as a commercially viable entity in the national economy. During 2007/2008, the total production of wheat was 1.57 million mt. At present rate, Nepal produced wheat worth of more than US\$ 400 million (NRs.27272.5 million).

\section{DISCUSSION}

Nepal started preparing the 'National Adaptation Program of Action' (NAPA) on climate change about six years ago. However, nothing substantial has been accomplished so far. The Nepal's NAPA seems to be focusing more on the effects on tourism, biodiversity, abnormal rain, storm, rapid melting of snow and glacier formation. Though these aspects are important too, the most important effect of climate change would be on agriculture (food production). Therefore, the country should be more concerned on the negative impact of climate change on the agriculture. Shortening of winter season, summer season getting hotter and erratic rainfall patterns as a result of climate change could have serious adverse impact on agriculture.

The issues of development of wheat yield and production lie in the following main points.

I) One of the reasons for increase in wheat yield is the use of improved seeds. About $97 \%$ of seeds used in Nepal during 2007/ 2008(MOAC, 2008) was improved. There are altogether 21 varieties of wheat developed for different environment in Nepal (NARC, 1997). In previous years there was general recommendation for seed rate of $100 \mathrm{~kg} / \mathrm{ha}$. Recent experiments have shown that additional seeds of 25 to $50 \mathrm{~kg}$ is required under late sown and under farmers broadcast system (NARC).

II) The other reason for improvement in wheat cultivation can be attributed to better irrigation facilities.

It seemed that the first irrigation used to provide during the crown root stage, but how much water had been provided, the records were not available. As a second application, during the grain filling stage of the wheat, it seems that very few farmers used to apply, but this is the critical period for water deficits in wheat. At this time the weather is very dry and the rain-fed rivers are almost dry. Therefore the occurrence of rainfall during that period seemed to be very important for the wheat production in Nepal. But due to the non availability of when and how much water had been added by the irrigation and at the same time the wheat yield and production data were just aggregated at district level. In 
that circumstance, how much rainfall affected in wheat production was a complex issue. Therefore, It is very necessary to stress that it is very important to have the data, when, where and how much water had been added. If the irrigation was available through out in Rupandehi, the fluctuation of the cultivation of wheat as well as the yield may not have varied as shown in Figures 8 and 9. Thus the collection of field observation of irrigation application is very much required, so that one can make the possible suggestions which can be laid down for the future planning and development.

It has been commonly observed that farmers put heavy irrigation in their wheat fields during first irrigation, that creates anaerobic situation for wheat plants and wheat plants start yellowing. This happens due to poor knowledge of wheat agronomy among farmers and poor drainage in the Tarai. After yellowing the wheat crop shows a fatal illness for a period of at least one week which is very important for yield attributing components in wheat. Because just after first irrigation (after 25 to 30 days of planting, the spike initiation starts and that decides the size and number of florets in the spike). This has to be taught to farmers to improve wheat yield and many farmers know this.

III) The third factor should be the fertilizer application and their quantities. Modern wheat varieties are very much responsive to fertilizer application and require 100:50:50 kg/ha NPK under irrigated conditions whereas in rain-fed wheat the addition of $25 \mathrm{~kg} / \mathrm{ha} \mathrm{K}$ in the previously recommended doses of 60:40 kg/ ha NP is beneficial. Experiments show that irrigation provided a sizeable increase in yields (NARC, 1997). It is understood that Nepal uses least amount of fertilizer in this region.

IV) The fourth factor is land fragmentation, small land parcels and small landholdings scattered across many places have been the major causes for under utilization of ground water irrigation. Moreover, marketing of commercial crops is not organized so as to benefit small to medium farmers, and the current high cost of crop production makes the growers unable to compete with similar products imported from India. Winter crops only less than $30 \%$ of projected command area of major irrigation projects get assured irrigation.

V) The fifth factor should be the better management of the field due to training and publicity given by extension workers from the Department of Agriculture. The farmers are not oriented towards maximizing the farm production, mainly due to lack of integrated water management and advanced agricultural technology and inputs. Irrigation and agriculture sector programs are not coordinated and theoretical ideas of crop intensification and diversification in areas where water is available for crops have not been put into practice by the agencies concerned (Shah \& Singh, 2003). This is the serious comment which has to be tackle for the future development in agriculture.

\section{CONCLUSION AND RECOMMENDATION}

The area of wheat cultivation in Nepal has increased drastically, by three folds, especially at the Tarai region as described earlier. Previously area of cultivation was very limited and the yield was less than $1 \mathrm{mt} / \mathrm{hectare}$ in Tarai. Now, with availability of the high yielding varieties as well as improved irrigation facilities in Tarai, wheat yield has increased more than three times in the Tarai. However, during the same period wheat yield showed $100 \%$ increase in the Hills and only $50 \%$ increase in the mountains.

Weather still plays a prominent role in crop productivity, but the coordination with related Departments is very poor. On the other hand, Department of Hydrology and Meteorology was 
focused only in aviation weather forecasting since the establishment of their services in 1960's. They should expand their boundaries for their services in agriculture. Department of Agriculture/ Ministry of Agriculture and Co-operatives need a better coordination with the different Department in future for their challenging role of Agriculture development in Nepal. The Ministry of Finance and Planning commission Secretariat should pay their attentions, if ever Department of Hydrology and Meteorology requests for the extra budget to play a supporting role for the development of Agriculture in Nepal.

The Ministry of Agriculture and Cooperatives in the Government of Nepal should be very serious and immediately establish a Monitoring and Evaluation Committee on climate change impact on agriculture. A country can not wait until the last minute and they have to fully prepare before any catastrophic consequences. Nepal has very few studies on weather, climate and crop relation studies. It is high time to study the variation and trend of past climate data and their relation to crop in detail. Any extreme occurrence of weather and climate event may damage the crop. Now it is known only that the global warming has been taking place since 1970's and the global temperature may increase by 1.4 to $5.8^{\circ} \mathrm{C}$ during this century (Global Circulation Models projection). This information is not enough for agriculture and therefore one has to know, what is going on at the different places in the country and what can be done. The present study showed that the mean annual temperatures were increased $0.0051^{\circ} \mathrm{C}, 0.0288^{\circ} \mathrm{C}$ and $0.035^{\circ} \mathrm{C}$ in Bhairahawa, Surkhet and Jumla during 19772008, but the mean temperature trend during the wheat growing season in Bhairahawa, Surkhet and Jumla were $0.012^{\circ} \mathrm{C}, 0.0323^{\circ} \mathrm{C}$ and 0.0368 during 1977-2008.

To address all the above mentioned issues, the concerned authorities i.e. the Ministry of Agriculture and Cooperatives should immediately take action and create a high level Monitoring and Evaluation Committee, which should also consider the objective method (i.e early agro-meteorological crop yield assessment developed by FAO 1986) of monitoring and evaluation of crop yield and production in Nepal. The importance of objective method was also discussed (Nayava, 1999). In addition to subjective method of monitoring and evaluation of crop yield and production, the objective method of monitoring and evaluation should be introduced. This will play a supporting role to monitor and evaluate the crop yield assessment in future. The high level Monitoring and Evaluation Committee will also discuss and assess the effect of climate change on crop yield and production at the district level. At the same time each district Irrigation Offices should also collect the information of irrigation application and their quantity and frequency. Finally, all the concerned agencies should bring their information and discuss and finalize the crop yield and production for that year. These kinds of discussion should evaluate whether each and every contributory factors such as planting date, weather condition, irrigation, fertilizer applications and any other factors during the crop growth cycle. In addition this will help to evaluate and pinpoint drawback and achievement of agricultural activities in each district. In other words, the integrated approach from different supporting agencies as well as stake holders will play a vital role in this present context for the agricultural development in Nepal. Any drawbacks to meet the target of that year in each district have to be fully discussed and materialized.

\section{ACKNOWLEDGEMENTS}

The authors sincerely acknowledge the Department of Hydrology and Meteorology, Kathmandu for providing the necessary climate data for this paper. The authors wish to thank Mr Jagannath Thapaliya, former Chief Economist, Ministry of Agriculture and Cooperatives for his suggestions to include marketing/value chain approach in wheat crop. The authors are grateful to Dr. Khem Raj Sharma, Department of Irrigation for his suggestions. 


\section{REFERENCES}

Briggle, L. W., 1980. Origin and Botany of wheat, In E. Hafliger (ed.) Wheat Documenta, Ciba-Geigy, Basel, Switzerland, pp.6-13.

CBS, 1994. National Sample Census of Agriculture, Nepal 91/92, Highlights, CBS, NPC, HMG of Nepal, Kathmandu.

CBS, 2003. Agricultural Statistics of Nepal, 2000/ 2003, CBS, NPC, HMG of Nepal, Kathmandu.

CBS, 2006. Monograph, Agriculture Census, Nepal, 2001/2002, CBS, NPC, Government of NBriggle, L. W. 1980. Origin and Botany of wheat, In E. Hafliger (ed.) Wheat Documenta, Ciba-Geigy, Basel, Switzerland, pp.6-13.

DFAMS, 1977. Agricultural Statistics of Nepal, 1977, Department of Food and Agricultural Marketing Services (DFAMS), Ministry of Agriculture (MoA), HMG of Nepal, Kathmandu.

DOI, 2004. Database for Irrigation Development in Nepal, IDS, Kathmandu.

FAO, 1979. Yield response to water, FAO Irrigation and Drainage Paper 33, Rome.

FAO, 1986. Early agrometeorological crop yield assessment, FAO Plant Production and Protection Paper 73, Rome

Fitzpatrick, E.A., and Nix. H.A. 1970. The climatic factor in Ausrralian grassland ecology, In Australian Grassland”. (Ed.Moore): The Australian University Press, Camnberra, Australia, pp. 3-26.

Journal of Hydrology and Meteorology, Vol. 6, No. 1
IPCC, 2007. Climata Change 2007: The Physical Science Basis, In Summary for Policy Makers, IPCC:21, Geneva: IPCC.

MoAC, 2006. Statistical Information on Nepalese Agriculture, 2005/2006, Ministry of Agriculture and Coperatives, Kathmandu.

MoAC, 2007. Statistical Information on Nepalese Agriculture, 2006/2007, Ministry of Agriculture and Coperatives, Kathmandu.

MoAC, 2008. Statistical Information on Nepalese Agriculture, 2007/2008, Ministry of Agriculture and Coperatives, Kathmandu.

NARC, 1997. 25 Years of wheat Research in Nepal (1972-1997), Nepal Agricultural Research Council, Kathmandu.

NARC, 2007. Released and registered crop varieties in Nepal, Nepal Agricultural Research Council, Kathmandu.

Nayava, J.L., 1981. Climates of Nepal and their implications for Agricultural Development, The Australian National University, Canberra, Australia, Ph.D. Thesis, pp 1-284.

Nayava, J.L., 1999. Monitoring and evaluation of crop yield and production in Nepal; Proceedings of $3^{\text {rd }}$ national conference on Science and Technology, Royal Nepal Academy of Science and Technology, Kathmandu. pp. 720-734.

Nayava, J.L., 2004. The temporal variations of rainfall in Nepal since 1971-2000, Journal of Hydrology and Meteorology, Volume 1, pp. 24-33. 
Nayava, J.L., 2008. Variations of rice yield with rainfall in Nepal during 1971-2000, Journal of Hydrology and Meteorology, Volume 1. pp. 93-102.

Shah, S.G., \& Singh G.N. 2001. Irrigation Development in Nepal Investment, Efficiency and Institution, Winrock International, research Report Series No. 47.

Sharma, A., 2007. Personnel Communication, National Agricultural Research Council, Khumaltar, Nepal.

Sharma, K.R., 1998. Institutional and technological options in the development and management of small scale irrigation systems, FAO water series, vol.17.
Sharma, K.R., 2004. Modalities of irrigation development and technology: Results from agency and farmers managed system, Irrigation conditions, vision and the concept of integrated water resources management, Department of irrigation, pp.66-77.

Shrestha, A. B., Wake, C.P, Mayewski, P.A. \& Dibb, J.E. (1999). Maximum temperature trends in the Himalaya and its vicinity: An analysis based on temperature records from Nepal for the period 197194, In Journal of Climate, 12: pp.27752767. 